\title{
B9. AVALIAÇÃo PRELIMINAR DE UMA BOMBA CENTRÍFUGA MAGNÉTICA E SEU IMPACTO NA VIABILIDADE DE CÉLULAS CHO.
}

Marina Vergne de Almeida ${ }^{1}$; Tiago Pereira dos Santos ${ }^{1}$; Esther Vinhais Guitierrez ${ }^{1}$; Maíra Peixoto Pellegrini ${ }^{1}$; Rodrigo Coelho Ventura Pinto ${ }^{1}$.

${ }^{1}$ Bio-Manguinhos / Fiocruz.

INTRODUÇÃo Células de mamíferos são cultivadas em suspensão, com agitação, de forma a manter uma distribuição homogênea de células, nutrientes, metabólitos e produto. Isto permite um monitoramento das condições da cultura, cultivos com maiores densidades e maior produção da proteína de interesse. Biorreatores operados em perfusão, com constante troca de meio de cultivo e retenção de células, necessitam de um sistema de recirculação por bombeamento que mantenha alta viabilidade, sem consequente impacto no produto. As bombas mais utilizadas na indústria biotecnológica são bombas peristálticas, no entanto, apresentam vazão relativamente baixa, fluxo e pressão intermitentes e alta tensão de cisalhamento. Bombas centrífugas com impelidor magnético começaram a ser aplicadas a processos biotecnológicos, já que não promovem atrito com o eixo do rotor, reduzindo a exposição das células ao estresse mecânico.

OBJETIVO Avaliar as condições operacionais de uma bomba centrífuga, com impelidor magnético, em uma linha de recirculação fechada e analisar o impacto na viabilidade de células $\mathrm{CHO}$.

METODOLOGIA A bomba foi conectada à linha de recirculação de um biorreator de 2L e a correlação entre velocidade de rotação e a vazão de bombeamento foi verificada a partir de uma curva de calibração, em uma faixa de 1000 a 3000rpm. $\mathrm{O}$ teste preliminar de recirculação com células $\mathrm{CHO}$ foi realizado com velocidade de 2000 rpm, com recirculação de 20 vezes o volume de cultivo. A viabilidade e concentração celular foram mensuradas em hemocitômetro com azul de tripan imediatamente após o reciclo e durante um período de 72 horas.

RESULTADOS A bomba foi operada por 18 minutos, atribuídos a uma recirculação de 20 vezes o volume do cultivo, admitindo-se que cada célula foi submetida ao 
ambiente da câmara de bombeamento 20 vezes. A concentração celular e viabilidade do cultivo foram mensuradas imediatamente após a operação, 2, 4, 24, 48 e 72 horas depois, sem identificar queda significativa na viabilidade celular (mantida acima de 80\%) nem prejuízo na concentração celular quando comparadas ao cultivo controle. Para evitar que o efeito da exaustão dos nutrientes interferisse nos resultados, o biorreator foi operado em modo continuo com taxas de diluição que variaram entre 0,4 e 0,6.

CONCLUSÃO A manutenção da viabilidade celular indica que o procedimento de recirculação das células no biorreator não causou estresse mecânico suficiente para induzir, de forma significativa, a morte celular, sugerindo que a utilização da bomba com a linhagem celular é viável. Vale ressaltar que o período de recirculação utilizado (18 minutos) é equivalente ao que é observado em um período de 24 horas de operação em escala industrial, no entanto com uma velocidade menor. Outras velocidades de operação serão testadas levando em consideração a frequência e a intensidade resultantes de diferentes vazões, para que seja possível estabelecer as condições ideais de operação do sistema.

PALAVRAS-CHAVE biorreator, bomba centrífuga, célula CHO. 